\title{
OPPORTUNITIES AND CHALLENGES IN THE IMPLEMENTATION OF TEN REVITALIZATION STRATEGIES OF VOCATIONAL SCHOOLS IN INDONESIA: SCHOOL PRINCIPALS' VOICES
}

\author{
Ahmad Kailani $^{1}$, Dina Rafidiyah ${ }^{2}$ \\ ${ }^{1,2}$ Universitas Muhammadiyah Banjarmasin
}

Corresponding author: ahmadikay@gmail.com

\begin{tabular}{l}
\hline Article Info \\
\hline Received : 09 September 2020 \\
Accepted : 05 October 2020 \\
Published : 22 October 2020
\end{tabular}

Keywords: Phenomenology

Study, Ten Revitalization Implementation Strategies, Private Vocational School, Public Vocational School

\section{Abstract}

The alumni of Vocational Schools (VS) have contributed to the increasing number of unemployment recently. At the onset, the main objective of vocational education is to produce ready to work alumni. However, the more the schools produce alumni, the higher the number of jobless people in this country. To tackle the issue, the government launch revitalization programs for VS's across Indonesia. The implementation of the program is intended to cut down the number of unemployment and poverty. To explore the implementation of the program within a vocational context, this study was undertaken to look at the understanding of VS principals about the revitalization programs as well as the ten core strategies of the program. Besides, the study was also conducted to explore the problems faced the principals and their expectations of the revitalization program. A qualitative phenomenology study using in-depth interviews were conducted to garner the data from nine school principals of private and public VS's in South Kalimantan Province, Indonesia. The findings indicate that the improvement of the competency of certified teachers is essential. Furthermore, the availability of business and industrial based (DUDI) facilities and learning resources, as well as the availability of professional development training through a link and match programs, are also important. On the other hand, the establishment of Management Information System (SIM) based on School Automation System (SAS), industry-based curriculum, teaching factory, tutorial video, local wisdom, and the role of VS as the triggers of the local economy needs more socialization by the government. 


\section{INTRODUCTION}

Unemployment has become a major problem in Indonesia for decades. This may become a serious problem, especially related to the demographical bonus from 2020 - 2030 (Tarma, 2016). According to The Central Statistics Agency (BPS), the Open Unemployment Rate in Indonesia as of February 2020 reached 6.88 million people, especially for alumni of Vocational School (VS) is still the highest among other education levels, which is 8.49 percent (Supriyatna \& Djailani, 2020). This is so ironic since the alumni of vocational education should be ready for work.

One of the most affecting factors is that the majority of alumni of vocational education is not qualified to work in the industry. Efendi, Radhia, \& Rizki (2017) stated that there is no common perception about concepts, work behavior, and management between industries and vocational education institutions, including the organization and coordination between the two. To solve the problem, the government has launched new regulations related to Vocational Education in the form of the Revitalization Program for VS's (Pracihara, 2017). To achieve that goal, the government also recommends ten strategies of VS revitalization, namely: (1) human resources revitalization; (2) developing school administration system based on management information system; (3) link and match with industry; (4) industrybased curriculum; (5) teaching factory; (6) using tutorial video as teaching media and creating e-report skill portfolio; (7) conduction professional certification test; (8) fulfillment of infrastructure; (9) local wisdom development; and (10) the role of vocational schools as local economic movement (Hadam, Rahayu, \& Ariyadi, 2017).

Previous studies were conducted to investigate the revitalization strategies of vocational schools, but not all strategies have been looked at because this topic is relatively new in Indonesia. The topics such as local wisdom development and the role of vocational schools as a local economic movement have never been researched. Thus, it is quite challenging to find references discussing strategies in vocational schools' revitalization. This program still needs more socialization to be implemented by vocational schools (Rafidiyah \& Kailani, 2020). Previous studies dominantly captured the development of human resources in handling the revitalization program. One of the literature reviews conducted by Khurniawan and Erda (2019) contends that there are four factors for sustainable vocational school revitalization: headmaster leadership, teachers' ability, students as the focus of learning, and the specific curriculum for each field of vocational education.

Previous studies report that teachers' roles are very important to prepare the readiness of the alumni, therefore, designing teacher professional development models through needs analysis, observation, and surveys is essential (Muhsin, 2017). Four model components of teacher professional development are teacher learning groups, teacher performance evaluation, teacher learning, and teacher portfolios (Abdurrahman, 2019). To improve teachers' competence and professionalism, it can be done by encouraging teachers to continue study to Master level, joining courses and training, attending seminars, publishing research on educational journals, and establishing cooperation with professional 
institutions (Borang, 2010). All in all, teacher and educational personnel professional development needs to be taken into account to improve human resources quality and professionalism which support the goals of revitalization programs (Irianti, Sulistyorini, \& Nafiah, 2017; Mariah \& Sari, 2019).

Furthermore, there was a study conducted on the link and match with industry, industrybased curriculum, and teaching factory inviting 20 machinery industries (Wibowo \& Munadi, 2019). The study concluded that there are six contributions of the machinery industry in the revitalization program, namely: building link and match; apprenticeship program; a teacher internship program; industry-based class program; curriculum development; and teaching factory program. The results showed that the contribution level was very low, while Nurlaela et al. (2019) mentioned that the key to the success of vocational revitalization is the collaboration between the industry, the vocational school, and universities. This is in line with the case study conducted by Muchtar (2019) in two vocational schools in Bandung. He mentioned that revitalization needs a strong management process such as planning, organizing, implementing, controlling, and evaluation, especially in link and match and industry-based curriculum. Those management processes could be done by developing a school administration system based on the management information system.

One of the industry-based curriculum concerns is the mastery of English ability for students of vocational schools through the bilingual learning ecosystem (Lee, Wahidiat, \& Khurniawan, 2017). For instance, there is an English Day Program in one of the vocational schools in Jakarta (Putri \& Yuyun, 2018) and the English Area Program in one of the vocational schools in Gorontalo (Miolo, Emzir, \& Rasyid, 2017). The study indicates that those programs worked well to motivate and encourage students to use English on daily basis. English mastery would help students before attending their job interviews since nowadays almost all the job interviews are in English (Rafidiyah \& Kailani, 2019).

Regarding the use of tutorial video and e-report skill portfolio, all participants claim these activities as the use of technology in teaching vocational school students. Efendi et al. (2017) infer that the use of technology in the industry should be in line with the one taught in the vocational school. Thus, building learning infrastructures that meet industry needs are essential to do. The mastery of technology advancement in the industries should be included in vocational curriculum content.

Another revitalization strategy that needs to undertake is the profession certification test. Suhirman (2019) conducted a learning need analysis study on the product processing program. The research proposes that vocational school curriculum need to be redesigned and transformed into an industry-based curriculum. Those competencies should be certified based on the National Work Competency Standard Test. Besides, teachers also should have minimum qualifications and certification under the level of teaching capability (Marissa, 2017). 
All the aforementioned studies have not touched in-depth on how the implementation of the revitalization in private and public vocational schools. Thus, an in-depth study is needed to see the implementation of revitalization programs at vocational schools, especially in South Kalimantan Province, as well as to explore school leaders' understanding of the program. This research is aimed to identify the problems faced encountered by school leaders regarding the implementation of revitalization at their schools and to inform plans for fixing human resources issues at VS.

\section{METHODOLOGY}

This is qualitative research with a phenomenological approach (Padilla-Díaz, 2015). This study aims to explore the understanding, implementation, and expectations of the school principals of Vocational Schools in Kalimantan Selatan Province regarding VS revitalization strategies in their respective institutions. This study also investigated the problems in the implementation of the revitalization strategy at VS. The participants of this research were nine headmasters or their deputies in Kalimantan Selatan Province. Four school principals of public vocational schools and five principals of private vocational schools of Muhammadiyah were invited to interviews. Among the selected schools, there were six VS which have received revitalization funding, two of them are private VS's whereas the other schools never receive the fund.

According to Creswell (2012), there are several stages of data collection with a phenomenological approach: First, looking for respondents who are willing to take part and the respondent category should be a school principal or school leader. This is because they are the policymakers who will determine future school revitalization strategies. Then each respondent is interviewed regarding their understanding of the implementation of ten strategies of revitalization, problems they faced, and their expectations of the revitalization program. The interviews were recorded in audio format. Then they were transcribed. Because of the COVID-19 Pandemic, some interviews and follow-up interviews were done by WhatsApp Chats. The result data were analyzed using a phenomenological approach. The analysis also includes comparing the phenomena between public vocational schools and private vocational schools.

Data analysis adopt the procedures by Moustakas (1994) as follows: (1) the researcher describes his personal experience of the phenomenon, (2) the phenomenon are drawn on from the interview data; (3) the researcher categorizes the results of the interview into broader themes or classifications; (4) the researcher describes the phenomenon based on the analysis of the text and examples; (5) the researcher combines textual and structural descriptions, then draws conclusions based on the essence of the phenomena that occur; (6) J. A. Smith (2007) interpretive analysis will be carried out to delve deeper into the phenomena so that the inferences are not superficial which only rely on what is written in the text of the interview results. 


\section{RESULT AND DISCUSSION}

\section{The Understanding of Vocational School Revitalization Strategies}

The findings indicate that all participants know about the revitalization program. They were able to explain the program in brief and the existing revitalization program they undertook. In general, they said that revitalization programs are dealt with the vision and missions of the school and equipping students with sufficient skills by providing the most updated supporting facilities. It can be inferred from the following narratives by a principal of a private vocational school and a principal of a public vocational school:

...to choose a school with big potential for development, the fulfillment of supporting facilities, the improvement of human resources, partnership with companies and industries, learning approach through teaching factory, industry class, and certification for teachers and students (PU4)

There are four components of revitalization: curriculum, teachers, alumni, and facilities. Regarding curriculum targets, schools are expected to be able to design a curriculum that matches the school's needs. Teachers need to be knowledgeable of the industry and distinctive skills the school offers. For final year students, the students will have a practicum test besides the national exam, internship exam, and they will sit for the expertise certification exam held by the National Certification Agency. (PR3)

For vocational schools which have not received revitalization fund, the principals said that they did the implementation but they did not know the revitalization program exactly. Even, there was one school principal of a private vocational school stated that he did not know the revitalization program until he received the fund.

..I have searched for further information regarding revitalization after my school received the aid. When I did the hajj pilgrimage, my school computer operator told me that our school was granted 1,9 billion rupiahs. (PR2)

Based on the narratives of the respondents, it can be concluded that the majority of the respondents know the ten core programs of revitalization; however, they cannot explain each program in detail. This is in line with the previous research findings on the implementation of the revitalization program conducted by Rafidiyah \& Kailani (2020). The study found that school principals still need more socialization about the program. There are only six strategies the respondents know well. Those strategies are the improvement of human resources, the availability of supporting facilities, industry-based curriculum, link and match, teaching factory, and certification of competency. The strategies the respondents have not stated, namely, the School Administration System, 
Information Management System, the use of video tutorials, the development of local wisdom, and the role of vocational schools as the local economy agents.

Generally speaking, the respondents understand the objectives of revitalization. They know the main objective of the program is to equip the alumni with sufficient knowledge and job skills so that the alumni will be ready for the real job competition.

Vocational School Revitalization aims to first create a link and match between schools and the world of business or industries. Second, changing the paradigm from push to pull. This means shifting the paradigm of vocational schools as the producer of new alumni into equipping the alumni with the work culture and job skills needed in industries. Third, changing learning from supply-driven to demand-driven. Fourth, prepare vocational school alumni to be more adaptable to the rapid changes in industry and businesses. Fifth, narrowing the gap between vocational education and the needs of the Business and Industrial World (DUDI) in terms of technology, administration, and competence. (PU4)

\section{The Implementation of Vocational School Revitalization Strategies}

In general, vocational schools with revitalization funds have started implementing these ten strategies, but not all of the implementation has been accomplished. On the other hand, some private vocational schools without revitalization funds have implemented the strategies. For more details, each strategy will be explained so that the implementation of the revitalization strategy in their respective schools can be seen clearly.

\section{a. Revitalization of human resources}

Two private vocational schools without revitalization funds have not used this strategy in their schools. Meanwhile, another vocational school has implemented one of the programs by sending teachers to attend training on teaching and curriculum. For the recipients of revitalization funds, human resource development becomes a priority, especially for the improvement of teachers' competency. This is illustrated by the following comments from the participants:

MGMP participation, seminars, workshops for teachers. Some were sent to Yogyakarta to join the PKG. For the TKR Automotive department, productive teachers are still lacking, so there are several Bachelor of Engineering who join PPG. There are 19 productive teachers in my school for 4 study programs. (PR2)

Especially for film study program teachers, they are sent to Jakarta to attend training conducted by the National Film Development Center. PPG training for teachers who are not linear uses their funds, while for 
teachers applying for competency certificates, it is funded by the school. (PU1)

In the same vein, the previous study highlight the importance of teachers' roles in conducting needs analysis, and joining professional development are essential to prepare students to be ready for work after they finish the school (Muhsin, 2017).

\section{b. Building SIM-based SAS}

Two private vocational schools that have not received revitalization funds have not used SAS or SIM at all, while one private school uses them to fill out e-report cards and TU but they are still offline. Meanwhile, vocational schools that have received revitalization funds have already used SIM-based SAS with different applications. In essence, the school administration system can be maximized so that it can save paper (paperless). This is good for the environment. As stated by the following respondents:

SAS has already been used, such as student payments, information for classes, and exams using CBT or paperless. (PR2)

The Majestik project from the government, ICT-based school management, so that it can make teaching and evaluation administration (e-report) so that it can be paperless. (PU2)

The findings are in line with what Muchtar (2019) has found that revitalization requires a strong management process through the development of a school administration system based on the management information system.

\section{c. Link and match with industry}

All schools stated that they have entered into an MoU with the business world and the industries (DUDI), especially for vocational schools whose majors which have been granted revitalization funds. As illustrated in the following interview:

The MoU with DUDI, School Committees, City and Regional Board of primary and secondary schools Agency of Muhammadiyah strongly support the school. The school has received as Rp. 400 billion for the revitalization. TKR majors in collaboration with Astra, Honda Trio Motor, TBSM, Chevrolet, Mitsubishi, Altrax. TKJ collaborates with Computer Information, Health Service, Tax Office, Telkom, PLN, other agencies, and District Offices. (PR2) 
First of all, we renewed the MoU with cooperation in the fields of internship, Teacher Internship, and alumni recruitment. After that, we held job matching by inviting the business world and industry who wanted to recruit employees. (PU4)

Wibowo \& Munadi (2019) state that link and match with industries can be undertaken through an industry based curriculum and teaching factory (Wibowo \& Munadi, 2019).

\section{d. Industry-Based Curriculum}

Only public vocational schools have implemented an industry-based curriculum. Meanwhile, the private ones still prioritize their programs on teaching English, although according to the school principals, the impact is not significant on the student. On the other hand, public vocational schools have begun to focus on the qualifications of alumni for industry needs, particularly for study programs that are granted revitalization. It can be seen from the results of the interview with the principal:

The Revitalization 2020 has been synchronized with Swissbell Hotel so that there is a shared curriculum according to DUDI qualifications. The learning process is $70 \%$ practicum and 30\% theory (online via Moodle / Edmodo / Google Class Room / Google Form). Especially for the use of English, the school strives for good English teachers, there are also extra-curricular English (especially hospitality study programs \& travel business). (PU1)

Especially for the culinary majoring, it already has an industrystandard kitchen (hotel and culinary). Regarding English day, it was implemented in the past but is no longer valid. The TOEIC test in collaboration with VIERA is carried out for free. Some alumni have studied abroad (at least 3 people per year). Overseas job offers already exist, but sometimes students feel hesitant to try it. In the past, there were student and teacher exchanges to the Philippines and Thailand funded by the school, but now there is no funding from the school committee anymore. Sometimes there are international exchange students who did an apprenticeship to schools to teach English. (PU2) 
We have one industry class, namely the Samsung class, the curriculum for vocational subjects is indeed provided by the Samsung Tech Institute, and students also still get regular vocational materials. (PU4)

From the narratives of the participant, it is clearly understood that English skill is necessary for vocational school students. One of the ways to improve student's English ability is through a bilingual learning ecosystem (Lee, Wahidiat, \& Khurniawan, 2017).

\section{e. Teaching factory}

Only one private vocational school has implemented a teaching factory. This school has received several revitalization funds and enormous support from the foundation that houses it so that it can get facilities that are under those used in the industrial world. As stated by the principal as follows:

Cooperating with 10 industries, including the spare part company. The workshop room is the same as TBSM (Motorcycle Business Engineering), the system for children learning, SOP is the same as the industry (dismantling motorbikes, etc.). (PR2)

Public Vocational Schools have implemented teaching factories in different ways according to the need for competency mastery of study programs in each school. In general, they use the block system as conveyed by the following two principals:

Still pioneering industry-based, in collaboration with Amaris Hotel, a learning model with a team, block system curriculum (practicum). (PU1)

By making a block schedule, a week for full vocational practicum, a week for general subjects, the problem is that we still have a lack of teachers, both vocational and general teachers. (PU4)

Nurlaela et al. (2019) mentioned that the key to the success of vocational revitalization is the collaboration between the industry, the vocational school, and universities. A teaching factory is a breakthrough where students can gain real learning experiences as much as possible during their studies. 


\section{f. The use of video tutorial media and video-based portfolio of e-report skills}

All schools have used the video tutorial media, even the LCD has been prepared by the school. Some of the videos were made by the teacher himself, but most of them still use videos from YouTube. Meanwhile, the video-based e-report portfolio has not been implemented by all schools, for several reasons, among others, because senior teachers are technologically illiterate and some skills cannot be done with the video, because they need direct guidance from the teacher such as culinary and sewing. When students make mistakes, the teacher can immediately anticipate them so that they can save the materials, as stated by the respondents:

Some teachers are approaching retirement age, so it is pointless to force them to apply it, unlike teachers who are still young. (PU4)

There have been several videos of table setting, restaurant, service, beauty, room set up, front office. There is also an e-module. For every teacher who writes an e-module, they will receive an incentive of Rp. 300.000, -. The target per semester is 5 modules, currently, the school already has 30 e-modules. The e-Report Skill Video-Based Portfolio cannot be implemented yet. There are several skills such as making cakes or sewing that need direct guidance to prevent wrong cutting or wrong procedures of cooking. For hospitality study programs, you can treat portfolios based on video e-report skills. (PU2)

Efendi et al. (2017) argue that the deployment of technology in the industry should be in line with the one taught in the vocational school.

\section{g. The exam of certification for the profession}

The strategy for the professional certification test for teachers of private vocational schools has not been implemented optimally. Many still rely on their funds. Another challenge is many teachers at private schools resign from the schools because they are accepted as PNS (state employees) and move to public schools. Even, many of the teachers have both an educator certificate and a certificate of competence. However, for public vocational schools, especially for majors that have already received revitalization funds, the certified teachers and with competency certificates are issued by the school. As stated by the following principal: 
Especially for teachers of the film study program, they are sent to Jakarta to attend training conducted by the National Film Development Center. Professional development training for teachers who do not have linear certificates is not funded, while for teachers applying for competency certificates, it is funded by the school. (PU1)

Thus, another revitalization strategy that needs to be considered is the profession certification test. Suhirman (2019) states that an industry-based curriculum should become revitalization program for the schools.

Meanwhile, students are required to pass the National Examination and get a certificate (LSP 1 / Professional Certification Agency 1), students are tested by teachers from other schools, while the certificate is issued by the National Certification Agency.

For students, we first submit a proposal to BNSP to get assistance in the Work Competency Certification Implementation (PSKK) program. If it has been approved and there is cooperation, then the implementation of PSKK will be scheduled at each Professional Certification Institute $(L S P)$. If the number of students exceeds the limit of assistance from BNSP, students are still included in the program, but at their own expense. Other vocational schools are also welcome to send their students to take the certification test at our school (PU4).

\section{h. The availability of supporting facilities}

Three private vocational schools are still in the process of proposing supporting facilities for improving the competence of their students. All vocational schools both public and private, which receive revitalization funds, especially those with competency expertise in receiving revitalization funds, get required facilities and infrastructure. However, other schools without revitalization funds, they still need financial assistance to provide these infrastructure facilities. As stated by one of the respondents:

Some of the facilities that are funded by revitalization funds: ovens and industrial kitchens (1/2 billion), industrial sewing machines, Hotel Edotel (3-star simulation), hotel laundry, Computer lab (with applications valued at Rp. 35 million for system hotels), 20 units of laptops, standard DUDI beauty tools (the complete body and face care). For arts and software engineering competencies (RPL) there are still not many supporting facilities available because they have not received revitalization funds. (PU2) 


\section{i. Developing local wisdom}

This strategy is interpreted differently by the school principals; four private vocational schools and one public vocational school emphasize on the learning and memorization of the Koran while other principals see local wisdom as the preservation of Banjarese culture:

... sasirangan craft is still introduced to students. (PRI)

... they are about the potential of the region, sasirangan craft, and Banjar traditional clothes (PU4).

\section{j. The role of vocational schools as a local economy catalyst}

One public vocational school and two private ones are still not implementing this strategy, while other schools have started implementing it by making efforts in their respective skill competencies. Some schools hold an exhibition once a year on the occasion of school birthdays. Other schools conduct training for the society as a community empowerment program. There is one vocational school has a School program to build a village, the concept already exists but is still not implemented.

Each department has a business, for example, TAV provides electronic repair services such as fans, laptops, etc.), TSM opens a motorcycle repair shop and laundry business. The profit is usually shared to support underprivileged students. (PR2)

The use of traditional medicines, such as making herbs or ginger candy, and these products are commercialized. (PR5)

Empowering students, for example in the production of granule sand, planting hydroponic vegetables, making chairs from used tires, cooperatives, travel agents (ASITA) which are managed by teachers and students. There are also Creative and Entrepreneurship Products (PKK) of students per group producing food and marketing it. (PU1)

The Vocational School "BUILDING VILLAGE" activity is being processed in collaboration between the schools and the village, ma'am ... because the village has the fund ... so they can be invited to work together ... to improve the skills of the young generation of villages... for training in partnership with the schools ... so that village funds can be channeled into a nation's asset for the future ... not just a mere 
consumptive distribution ... then there is a contribution of vocational schools to build villages... this is still a lan but until now it has not been realized ... because the village is not ready .. still afraid if something goes wrong in the use offunds .. yes ma'am. (PU3)

We also collaborate with craftsmen, to buy sasirangan fabrics. We also train the local community, especially housewives, to learn how to make clothes, and some of them are recruited to work in school convection. (PU4)

\section{The Existing Problems in Implementing Vocational School Revitalization Strategies}

Only one school stated that it has no internal problems in implementing the revitalization strategy. However, five public and private vocational schools stated that they have an internal problem that needs to be resolved. The problems such as the lack of teachers, especially productive teachers. It seems that this problem is common throughout Indonesia.

There is a need for financial support from the government for the development of workshops, complete science lab infrastructure is needed, additional rooms are needed, many teachers are only honorary teachers, so that they can leave if they are accepted as civil servants or move to other educational institutions, limited teachers follow certification test, teacher salaries are too small to pay for training. Principals have to attend training for Rp. 20 million so that they can have a NUK (School Principal Identification Number) and the school cannot afford all these activities. Supporting funds are lacking, on average, our students are middle to lower class, so we have to think about a priority. High operational costs do not let very expensive automotive practical items burden students. (PR2)

Human resources are still far from what they should be, the location is less strategic, far from road access, lack of coordination between teachers. (PR4)

Lack of productive teachers, so that each productive teacher must teach 30 hours in one week. There is a plan to divert normative teachers (English, Indonesian, Mathematics) and adaptive teachers (sports/chemistry/physics/biology) to gain dual expertise by taking 1 year of training at P4TK, but the training is usually in cities or islands. others such as in Medan, Jogja, Jakarta. The difficulty of tools (facilities/infrastructure) because the tools available in schools are different from those used in DUDI. To overcome the problem, an apprenticeship program will be undertaken for student habituation. Limited funding is also a problem. Currently, each child receives 
BOSDA funds of Rp. 1,000,000, - whereas to be able to meet all the learning needs, at least, per student, we need Rp. 5,000,000, -, while the funds from the School Committee are only in the form of donations (PU1).

The English-language curriculum has not been well implemented, even though there are already some alumni who study abroad. The language laboratory already exists but the mixer is broken. (PU2)

Regarding external problems, only one school stated that there was no problem, while the other school principals stated that there were various external problems, as expressed by the respondents as follows:

We have to compete with public schools in terms of the recruitment of new students, so the number of students has decreased. 3 years ago we received 8 classes while 2 years ago to 6 classes, and last year we received only 4 classes, and there are small classes. Alhamdulillah, this year there is an increase because state schools want to reduce the number of student admissions from 1,300 to 800. (PR2)

Parents' support is still lacking, the leadership of the Muhammadiyah branch that oversees them has not mastered the strategy of developing the school (PR3)

Student motivation to attend school is low, the economic status of the family is classified as the lower middle. (PR4)

Alumni of Pharmacy Vocational Schools based on the existing Health Law are not allowed to prescribe medication, even though they have the competence. (PR5)

The payment of revitalization funds from the Provincial Education and Culture Office is often hampered because they have to wait for all schools to complete the current year report before they can submit for the next year's budget. Applications for the development assistance or grants are currently detected by the system using satellites, so if there is no exact location of the school, the grant funds will not be given. Buying goods should be done through the application called "school shop", no direct purchasing at the stores. Another problem is the lack of apprenticeship places, consequently, the apprenticeship is not appropriate. But this usually happens for several private schools, because usually, the apprenticeship places will prioritize public schools. (PU1)

Lack of DUDI Fashion study program, resulting in a lack of internships for students. Likewise, it also happens to the beauty study program, students are only able to do internships at small scale beauty salons. It is 
expected that alumni can do internships at companies such as Marta Tilaar. There are not too many multinational companies in South Kalimantan Province, so the options for the job market are very limited. (PU2)

Policy regulations or regulations, as well as budgets and time, are not synchronized in terms of quantity and timing of implementation. (PU3)

There is not yet adequate support from the local government, funding assistance and there is no monitoring, evaluation, and follow-up. (PU4)

\section{The Expectations of Respondents on the Vocational School Revitalization Implementation}

Four school principals of the private vocational schools expect the support of the government, parents, and foundations to add some infrastructure related to student competency skills. the principal of a private vocational school in pharmacy is that about a change in regulations relating to their graduates:

There should be a policy change, thus, the alumni of the Pharmacy Vocational School can work in pharmacies with a clear legal basis. Hopefully, the change in the form of the institution to SMKM 5 can open up many opportunities to develop new competencies that suit the needs of society. (PR 5)

Principals of public vocational high schools in this case have more diverse expectations, some are general or specific to their respective competency groups.

There is a paradigm of stakeholder thinking, changes in activities, the existence of industrial classes, that meet industrial needs. There is a product-based change model so that it can support the welfare of school members, both students, and teachers. (PU1)

The hope is that the revitalization can continue so that all competencies can be supported by the development funds. Can do a teaching factory at Roti Boy as a sub-contractor, for motorbike service it can go to Trio Motor, and for fashion to TELADAN, so that the quality can match DUDI but it can be implemented in Banjarmasin. (PU2)

Revitalizing workshops (machines and equipment), revitalizing human resources (adding more human resources because many of the existing human resources have retired), and revitalizing ITE (networks, capacity, and equipment). (PU3) 
Vocational school revitalization should begin with a mapping, including paying attention to the existing resources where the school is located, then be assisted according to the potential of the school. A stimulus is given in the form of funds by the direction of the school development. The direction of revitalization should provide more competence to students so that graduates can be independent and depend on the world of industry, the direction is more to instill an entrepreneurial spirit, not the competence of alumni as workers. (PU4)

However, all the 10 categories should not be implemented simultaneously if the school resources are not ready yet. Alternatively, each strategy that can be implemented stage by stage depends on the school priority depends on the needs of industries. Muchtar (2019) argues that further socialization programs for principals, teachers, and students need to do for all stakeholders to be able to gain a complete picture of the program. He emphasized that to get mutual development the public vocational schools should hand-on-hand with private vocational schools to do revitalization process.

\section{CONCLUSION}

Based on the findings, it is an urgent agenda for the government to support the program of professional development of certified teachers at vocational schools. The availability of supporting facilities that meet students' learning needs is a must to do the program to give students real learning experience before they step into real industries. On the other hand, the establishment of Management Information System (SIM) based on School Automation System (SAS), industry-based curriculum, teaching factory, tutorial video, local wisdom, and the role of VS as the triggers of the local economy needs more socialization by the government. This study is relatively new and needs further research in the same field. Studies on students' and teachers' perceptions and experience of the revitalization program would be an interesting topic to delve into for a future study.

\section{REFERENCES}

Abdurrahman, M. (2019). Konseptual model pengembangan keprofesionalitasan guru kejuruan SMK. Seminar Nasional Asosiasi Pendidikan Teknologi Dan Kejuruan Indonesia (APTEKINDO) 2018, 141-149.

Borang, D. S. (2010). Upaya peningkatan kompetensi dan profesionalisme guru SMK di era sertifikasi. Seminar Internasional Peran LPTK Dalam Pengembangan Pendidikan Vokasi Di Indonesia, 245-250. Retrieved from

http://scholar.google.co.id/scholar_url?url=https\%3A\%2F\%2Fejournal.undiksha.ac.id \%2Findex.php\%2FAPTEKINDO\%2Farticle\%2Fdownload\%2F67\%2F61\&hl=id\&sa= T\&oi=ggp\&ct=res\&cd=0\&d=14192830186105454022\&ei=SeJ1Xq3xEYaE6rQP6fW 
6AY\&scisig=AAGBfm1hUUZS4keDxCiUc3DRNw6YBHm

Creswell, J. W. (2012). Educational research: Planning, conducting, and evaluating quantitative and qualitative research. In P. A. Smith (Ed.), Educational Research (Fourth Edi). https://doi.org/10.1017/CBO9781107415324.004

Efendi, D., Radhia, \& Rizki, R. (2017). Problematika lulusan SMK yang banyak pengangguran. INVOTEK: Jurnal Inovasi, Vokasional Dan Teknologi, 17(2), 1-10.

Hadam, S., Rahayu, N., \& Ariyadi, A. N. (2017). Strategi implementasi revitalisasi SMK. In Buku Serial Revitalisasi SMK. https://doi.org/10.1300/J028v11n01_10

Irianti, A. H. S., Sulistyorini, S., \& Nafiah, A. (2017). Teacher preparedness and education personnel facing the revitalization of vocational secondary schools. International Conference on Vocational Education and Training (ICOVET 2017), 116, 196-201. https://doi.org/10.2991/icovet-17.2017.42

Khurniawan, A. W., \& Erda, G. (2019). Peningkatan mutu pendidikan SMK melalui revitalisasi berkelanjutan. Vocational Education Policy, 1(19), 1-14.

Lee, J., Wahidiat, S., \& Khurniawan, A. W. (2017). Startegi implementasi revitalisasi SMK melalui bilingual learning ecosystem. https://doi.org/10.1007/s00253-011-3237-z

Mariah, S., \& Sari, A. S. (2019). Revitalizing the role of teachers in practice learning to increase vocational students readiness. Journal of Physics: Conference Series, 1273, 1-8. https://doi.org/10.1088/1742-6596/1273/1/012039

Marissa, N. (2017). Upaya meningkatkan kompetensi dan profesionalisme guru pada era sertifikasi. Jurnal Meretas, 4(2), 78-86. https://doi.org/10.1119/1.4789885

Miolo, S. T., Emzir, E., \& Rasyid, Y. (2017). English Speaking Learning through The "English Area" Program in SMK Negeri I Gorontalo. JETL (Journal Of Education, Teaching and Learning), 2(2), 133. https://doi.org/10.26737/jetl.v2i2.276

Moustakas, C. (1994). Phenomenological research methods. Sage Publication, 154-157. https://doi.org/10.4135/9781412995658

Muchtar, H. S. (2019). Manajemen revitalisasi sekolah menengah kejuruan dalam upaya meningkatkan mutu lulusan. Nusantara Education Review, 2(3), 277-286.

Muhsin. (2017). Analisis kebutuhan konseptual model pengembangan keprofesionalan guru kejuruan SMK. Jurnal Auto Tech, 9(2), 246-253.

Nurlaela, L., Wibawa, S. C., Handajani, S., Wahini, M., Miranti, M. G., \& Romadhoni, I. F. (2019). Preparing competitive graduates of vocational school through revitalization program. 1st International Conference on Education, Social Sciences and Humanities (ICESSHum 2019), 335, 376-381. https://doi.org/10.2991/icesshum-19.2019.61 
Padilla-Díaz, M. (2015). Phenomenology in educational qualitative research: Philosophy as science or philosophical science? International Journal of Educational Excellence, 1(2), 101-110. https://doi.org/10.18562/IJEE.2015.0009

Pracihara, B. (2017). Instruksi Presiden No 9 tahun 2016 ( Revitalisasi SMK) memacu SMK bidang seni dan industri kreatif dalam pengembangan ekonomi kreatif. Seminar Nasional Seni Dan Desain : Membangun Tradisi Inovasi Melalui Riset Berbasis Praktik Seni Dan Desain. FBS Unesa., 313-319.

Putri, S. A. S. M., \& Yuyun, I. (2018). Evaluasi pelaksanan English Day di Sekolah Mengenah BPK Penabur Jakarta. Prosiding Seminar Nasional Hasil Pengabdian Kepada Masyarakat, 3(1), 203-208.

Rafidiyah, D., \& Kailani, A. (2019). Revitalisasi pengajaran Bahasa Inggris di SMK: Solusi konkrit bagi permasalahan pengangguran di Indonesia. In Rekomendasi kebijakan 100 hari pertama Jokowi-Ma'ruf Amin (p. 140).

Rafidiyah, D., \& Kailani, A. (2020). Identifikasi potensi SMK Muhammadiyah sebagai lembaga pendidikan vokasi yang berkemajuan: Studi fenomenologi terhadap penerapan program revitalisasi SMK di Indonesia. Pedagogik Jurnal Pendidikan, 15(1), 49-66. https://doi.org/10.1017/CBO9781107415324.004

Smith, J. A. (2007). Beyond the divide between cognition and discourse : Using interpretative phenomenological analysis in health psychology. https://doi.org/10.1080/08870449608400256

Suhirman. (2019). Revitalisasi pendidikan kejuruan agribisnis pengolahan hasil pertanian melalui pengembangan kurikulum berbasis industri, teaching factory dan sertifikasi kompetensi. Jurnal Rekayasa Dan Manajemen Agroindustri, 7(2), 279-291.

Supriyatna, I., \& Djailani, M. F. (2020). 6,88 juta pengangguran di Indonesia paling banyak lulusan SMK. Retrieved May 23, 2020, from suara.com website: https://www.suara.com/bisnis/2020/05/05/150000/688-juta-pengangguran-diindonesia-paling-banyak-lulusan-smk

Tarma. (2016). Corporate Vocational School: Strategi antisipatif menghadapi pengangguran lulusan SMK dalam prespektif bonus demografi. Jurnal Dinamika Manajemen Pendidikan, 1(1), 1-6. Retrieved from http://ir.obihiro.ac.jp/dspace/handle/10322/3933

Wibowo, A. E., \& Munadi, S. (2019). Machining industry's contribution level in vocational high school revitalization. IOP Conference Series: Materials Science and Engineering, 535(1-8). https://doi.org/10.1088/1757-899X/535/1/012026 